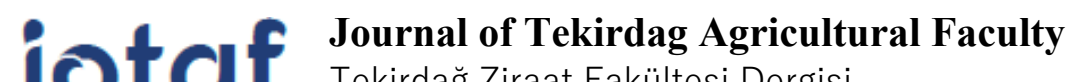 \\ Tekirdağ Ziraat Fakültesi Dergisi
}

\section{Morphological Characterization of Some Hybrid Red Head Cabbage (Brassica oleracea L.var. capitata subvar. rubra) Varieties}

\author{
Bazı Hibrit Kırmızı Baş Lahana (Brassica oleracea L. var. capitata subvar. rubra) \\ Çeşitlerinin Morfolojik Karakterizasyonu
}

\section{Mehtap ÖZBAKIR ÖZER ${ }^{1^{*}}$, Hayati KAR ${ }^{2}$, Şenay MURAT DOĞRU ${ }^{3}$, Nur KOBAL BEKAR ${ }^{4}$}

\begin{abstract}
This research aims to determine the morphological characteristics of different hybrid varieties in red head cabbage varieties, which has an important share in vegetable production, in Samsun province. In this study carried out at the Black Sea Agricultural Research Institute, 15 hybrid varieties were examined in terms of 28 different characteristics. Significant variations were observed in terms of the characteristics studied among hybrid varieties. Plant length varied between $36.33-57.67 \mathrm{~cm}$, plant width varied between $61.67-97.33 \mathrm{~cm}$, head weight varied between $905.0-1693.33 \mathrm{~g}$, length of outer leaf varied between $32.83-46.33 \mathrm{~cm}$, the width of outer leaf varied between 21.5-37.33 cm, length of head varied between $13.67-18.83 \mathrm{~cm}$, the diameter of head ranged from 11.53$14.67 \mathrm{~cm}$, length of interior stem varied between $5.63-8.67 \mathrm{~cm}$ and diameter of interior stem varied between 2.33$3.83 \mathrm{~cm}$. It was found that the outer leaves covered the upper part of the head, the hardness of the head was very tight, the shape of the head was broad obovate, and the outer leaves of the heads had a dark violet color. The period from seedling planting to the maturation of the heads varied 68 to 125 days, and all varieties remained in the field for a long time without cracking. Yaldiz is determined as the best variety in head weight, head length, and head diameter, traits correlated with cabbage yield. In addition, the highest plant height was observed in Caballero variety, and the highest plant width was observed in Red Taste variety. Remala is determined as the earliest variety, and Red Charisma is determined as the latest variety. It is thought that the varieties that become prominent in terms of head weight, head shape, head color characteristics in red head cabbage can be evaluated in hybridization and variety development studies.
\end{abstract}

Keywords: Red head cabbage, Morphological characterization, Variety, Yield, Hybrid

\footnotetext{
1*Sorumlu Yazar/Corresponding Author: Mehtap Özbakır Özer, Black Sea Agricultural Research Institue, Samsun, Turkey. E-mail: mehtap_ozbakir@hotmail.com (D) OrcID: 0000-0002-9519-2169

${ }^{2}$ Hayati Kar, Black Sea Agricultural Research Institue, Samsun, Turkey. E-mail: hayati.kar@tarimorman.gov.tr (D) OrcID: 0000-0002-7911-9295.

${ }^{3}$ Senay Murat Dogru" Black Sea Agricultural Research Institue, Samsun, Turkey. E-mail: senaymurat86@gmail.com (D) OrcID: 0000-0001-7794-0365

${ }^{4}$ Nur Kobal Bekar, Black Sea Agricultural Research Instıtue, Samsun, Turkey E-mail: n.kbekar@hotmail.com ODrcID: 0000-0001-7803-4380

Atıf/Citation: Özbakır Özer, M., Kar, H., Doğru, Ş.M., Bekar, N.K. Morphological Characterization of Some Hybrid Red Head Cabbage (Brassica oleracea L. var. capitata subvar. rubra) Varieties. Tekirdă̆ Ziraat Fakültesi Dergisi, 18 (3), 428-435.

CBu çalışma Tekirdağ Namık Kemal Üniversitesi tarafından Creative Commons Lisansı (https://creativecommons.org/licenses/by-nc/4.0/)

kapsamında yayınlanmıştır. Tekirdağ 2021
} 


\section{$\ddot{\mathbf{O} z}$}

Bu araştırma ile Samsun ili sebze üretiminde önemli bir paya sahip olan farklı hibrit kırmızı baş lahana çeşitlerinin morfolojik özellikleri belirlenmiştir. Karadeniz Tarımsal Araştırma Enstitüsü’nde yürütülen bu çalışmada 15 adet hibrit kırmızı baş lahana çeşidi 28 farklı özellik yönünden incelenmiştir. Hibrit çeşitler arasında incelenen özellikler bakımından büyük bir varyasyon olduğu tespit edilmiştir. Çeşitlerde bitki boyu $36.33 \mathrm{~cm}$ ile $57.67 \mathrm{~cm}$, bitki eni $61.67 \mathrm{~cm}$ ile $97.33 \mathrm{~cm}$, baş ağırlığ 905.0 g ile $1693.33 \mathrm{~g}$, yaprak uzunluğu $32.83 \mathrm{~cm}$ ile $46.33 \mathrm{~cm}$, yaprak eni $21.5 \mathrm{~cm}$ ile $37.33 \mathrm{~cm}$, baş uzunluğu $13.67 \mathrm{~cm}$ ile $18.83 \mathrm{~cm}$, baş çap1 $11.53 \mathrm{~cm}$ ile $14.67 \mathrm{~cm}$, iç sap uzunluğu $5.63 \mathrm{~cm}$ ile $8.67 \mathrm{~cm}$, iç sap çapı ise $2.33 \mathrm{~cm}$ ile $3.83 \mathrm{~cm}$ arasında değişmiştir. Kırmızı baş lahana çeşitlerinde başın üst kısmının dış yapraklar tarafından örtülü, baş sertliğinin çok sıkı, baş şeklinin geniş yumurta ve başlarda diş yaprak renginin koyu menekşe olduğu belirlenmiştir. Fide dikiminden başların olgunlaşmasına kadar geçen sürenin 68 ile 125 gün arasında değiştiği ve hibrit çeşitlerin tamamının arazide uzun süre çatlamadan kaldığ gözlenmiştir. Çalışmada verime etki eden önemli özelliklerden baş ağırlığı, baş uzunluğu ve baş çapı yönünden performansı en iyi olan çeşidin Yaldız olduğu tespit edilmiştir. Ayrıca en yüksek bitki boyu Caballero çeşidinde belirlenirken, en yüksek bitki eni ise Red Taste çeşidinde saptanmıştır. Olgunlaşma süreleri yönünden değerlendirildiğinde Remala çeşidinin erkenci, Red Charisma çeşidinin ise geççi olduğu belirlenmiştir. Kırmızı baş lahana da baş ağırlığı, baş şekli ve baş rengi ve mumsuluk özellikleri bakımından öne çıkan bu çeşitlerin melezlemeler ile çeşit geliştirme çalışmalarında değerlendirilebileceği düşünülmektedir.

Anahtar Kelimeler: Kırmızı baş lahana, Morfolojik karakterizasyon, Çeşit, Verim, Hibrit 


\section{Introduction}

Brassica is a genus that belongs to the 'Brassicaceae' family, known as the mustard family. There are 159 species in the Brassica genus (Zhou, 2001; Zhou et al., 2006). Brassica vegetables consist of Brassica oleracea and Brassica campestris species (Monteiro and Lunn, 1998). The important Brassica vegetables are listed as; head cabbage (var. capitata), acephala, garden cultivars (var. acephala), savoy cabbage (var. sabauda), cauliflower and romanesco (var. botrytis), broccoli (var. italica), brussels sprouts (var. gemmifera), kohlrabi (var. gongylodes), Kai-lan, Chinese leaf sprouts (var. alboglabra), Tronchuda cabbage (var. costata), curly kale (var. sabellica), palm cabbage (var. palmifolia), marrow cabbage (var. medullosa) and wild cabbage (B. oleracea var. oleracea). (Song et al., 1988; Song et al., 1990).

Although many different types of cabbage are cultivated worldwide, white cabbage, red head cabbage and leaf cabbage are grown and consumed more commonly in our country (Yağmur et al., 2003). Red head cabbage is a winter vegetable with an important place in human nutrition with its high antioxidants and fiber content. In addition, it is cultivated intensively in our country and has great economic importance. While cabbage is a vegetable consumed primarily in winter in our country, it has been consumed throughout the year except for 1-2 months (Onus and Polat, 2000). Red head cabbage production of our country is 187.948 tons. With 109.570 tons, Samsun is the largest producer of red cabbage, accounting for nearly $57 \%$ of its production. Samsun is followed by Konya (12.356 tons), Antalya (11.631 tons) and Bursa (10.477 tons) provinces (TUIK, 2018).

Red head cabbage has a rich genetic diversity because it is a highly cross-pollinated vegetable. For this reason, it can be grown in different ecologies both in the world and in many parts of our country. Today, F1 hybrid varieties are used extensively in vegetable production due to their superior properties such as earliness, yield, quality, homogenous development, resistance to biotic and abiotic stress conditions. In our country, hybrid varieties are mostly used in red head cabbage cultivation.

This research, it is aimed to determine the morphological characteristics, growth habits, earliness, and productivity levels of redhead cabbage hybrid cultivars grown in Samsun ecological conditions.

\section{Materials and Methods}

This research was carried out at the Black Sea Agricultural Research Institute in 2018 and 2019. 15 hybrid red head cabbage varieties (Pedro, Alex, Anexa, Red Charisma, Yaldız, Huzaro, Davaro, Remala, Caballero, Red Taste, Resima, Bandolero, Klimaro, Ametist and Maestro) were used as plant material.

The seeds of red head cabbage varieties were sown on 16 July 2018 at Black Sea Agricultural Research Institute. Seedlings were grown in an unheated plastic greenhouse. For seedling cultivation, seed trays ( 45 cells) with a 5.5 x $5.5 \mathrm{~cm}$ cell size were used. Growing medium formed from a 3:1 mixture of peat and perlite. Twenty seedlings for each red head cabbage genotypes were planted at the 4 to 5 true leaf stage with a plant spacing of $70 \times 30 \mathrm{~cm}$ in the second week of August. The study was carried out according to a randomized block experimental design. During the study, cultural procedures (irrigation, fertilization, weed cleaning, etc.) were carried out regularly.

Morphological characterization of the materials was carried out in the period of head-formation and harvest, and observations and measurements were made according to the criteria of the International Association for the Protection of New Plant Varieties (UPOV, 2004) and the International Institute for Plant Genetic Research (IPGRI, 1990). A total of 28 traits were examined in each variety (Table 1). 


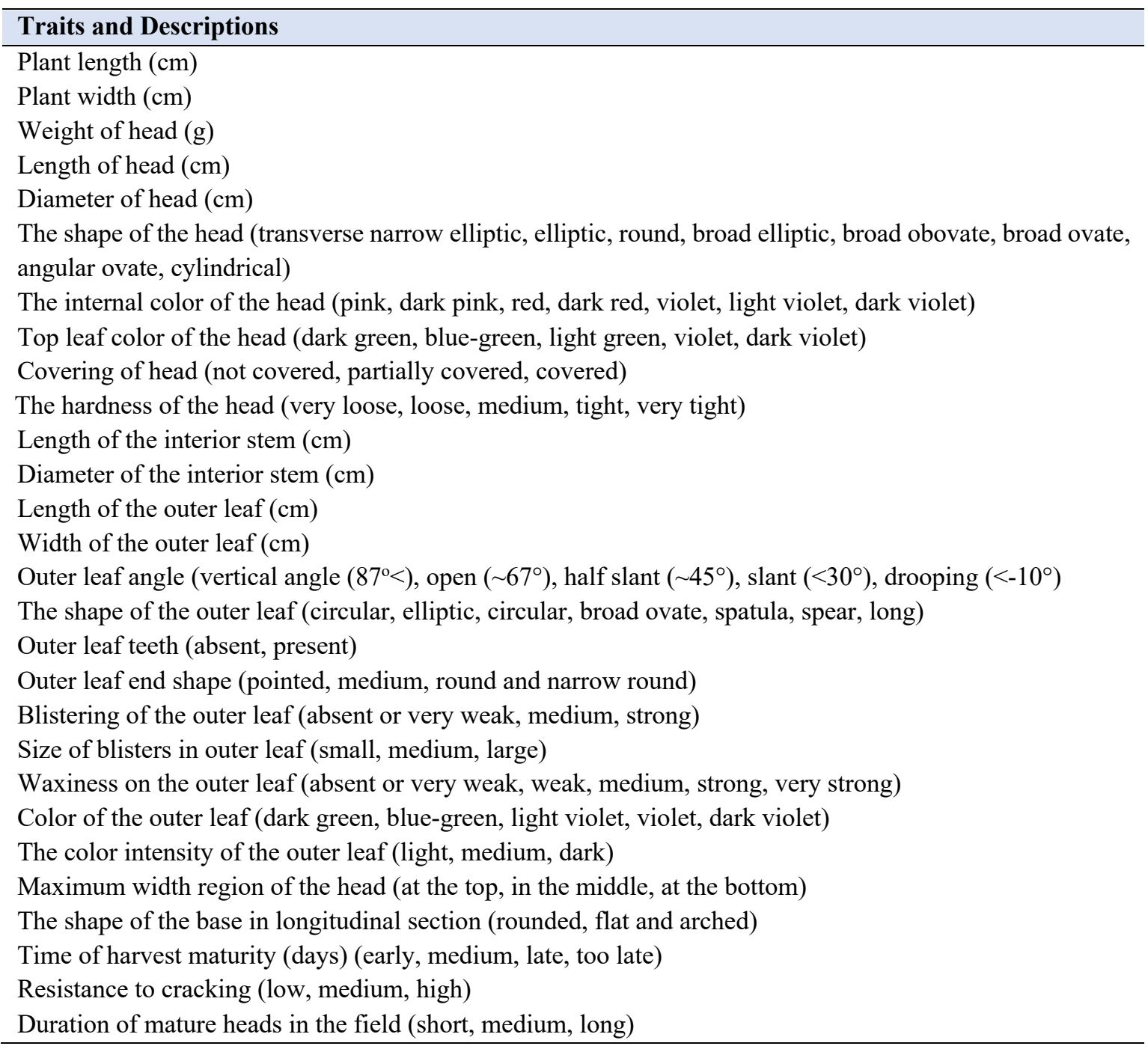

Analysis of variance was performed using the (ANOVA) package program of the obtained data. Duncan's multiple comparison test determined $\mathrm{P}=0.01$ significance levels.

\section{Results and Discussion}

In the study, the plant length value of varieties varied between 36.33 and $57.67 \mathrm{~cm}$. The lowest plant length was determined in Maestro, and the highest plant length was determined in Caballero varieties (Table 2). Among the redhead cabbage varieties, the lowest plant width was $61.67 \mathrm{~cm}$ in the Alex variety, and the highest plant width was $97.33 \mathrm{~cm}$ in the Red Taste variety. Acar and Paksoy (2006) determined the plant length as $25.02 \mathrm{~cm}$ in ACN33 F1 red head cabbage variety and $24.99 \mathrm{~cm}$ in Royal F1 variety. Aşçığul (2009) was determined that the plant length was $74.00 \mathrm{~cm}$ and width of the plant was $79.33 \mathrm{~cm}$ in redhead cabbage. The plant length of redhead cabbage was reported by Thapa and Prassad (2012) as 69.5 in Red Quen variety by Maltaş et al. (2017) as $23.06 \mathrm{~cm}$ and by Salwa et al. (2019) as $27.51 \mathrm{~cm}$.

The length of the outer leaf varied between $32.83 \mathrm{~cm}$ and $46.33 \mathrm{~cm}$, and the width of the outer leaf varied between $21.50 \mathrm{~cm}$ and $37.33 \mathrm{~cm}$ in the examined varieties (Table 2). While Aşçığul (2009) determined the length of outer leaf as 29.2-33 cm and the width of outer leaf as $30.33 \mathrm{~cm}$ in redhead cabbage, Salwa et al. (2019) were found the length of outer leaf as $21.24 \mathrm{~cm}$ and the width of outer leaf as $13.43 \mathrm{~cm}$. It was determined that the cultivars had mostly spatula leaf shapes. However some of the varieties had broad ovate and circular leaf shapes (Table 3). Outer leaf end shape is determined as narrow rounded in Resima and Caballero varieties and is determined as broadly rounded in other varieties. In most of the red head cabbage varieties, blistering of the outer 
Özbakır Özer \& Kar\& Doğru \& Bekar Morphological Characterization of Some Hybrid Red Head Cabbage (Brassica oleracea L. var. capitata subvar. rubra) Varieties leaf could not be detected. Size of blisters in outer leaf characteristic, which was determined as the medium in the leaves of the Klimaro cultivar and as large in the leaves of the Anexa, Remala, and Huzaro cultivars, could not be detected among the other red head cabbage cultivars. Waxiness is a desired feature in red head cabbage leaves and heads. Moreover, it was determined as strong in Klimaro and Red Charisma varieties (Table 3).

Table 2. Morphological characterization parameters of red head cabbage varieties

\begin{tabular}{|c|c|c|c|c|c|c|c|c|c|}
\hline Variety & $\begin{array}{l}\text { Plant } \\
\text { length }\end{array}$ & $\begin{array}{l}\text { Plant } \\
\text { width }\end{array}$ & $\begin{array}{l}\text { Weight of } \\
\text { head }\end{array}$ & $\begin{array}{l}\text { Length of } \\
\text { outer leaf }\end{array}$ & $\begin{array}{l}\text { Width of } \\
\text { outer leaf }\end{array}$ & $\begin{array}{l}\text { Length of } \\
\text { head }\end{array}$ & $\begin{array}{c}\text { Diameter } \\
\text { of head }\end{array}$ & $\begin{array}{c}\text { Length of } \\
\text { interior } \\
\text { stem }\end{array}$ & $\begin{array}{l}\text { Diameter of } \\
\text { interior stem }\end{array}$ \\
\hline Kaberola & $57.67 \mathrm{a}$ & $92.33 \mathrm{~b}$ & $973.33 \mathrm{e}$ & $43.70 \mathrm{bc}$ & $23.00 \mathrm{~h}$ & $15.50 \mathrm{fg}$ & $11.53 \mathrm{f}$ & $6.43 \mathrm{fgh}$ & $3.23 \mathrm{bc}$ \\
\hline Red Taste & $54.33 \mathrm{~b}$ & $97.33 \mathrm{a}$ & $1131.67 \mathrm{~d}$ & $46.33 \mathrm{a}$ & $31.67 \mathrm{cde}$ & $15.00 \mathrm{~g}$ & $12.00 \mathrm{ef}$ & $5.87 \mathrm{~h} 1$ & $2.60 \mathrm{fg}$ \\
\hline Resima & $54.00 \mathrm{~b}$ & $92.00 \mathrm{~b}$ & $1223.33 \mathrm{c}$ & $43.93 \mathrm{bc}$ & $37.33 \mathrm{a}$ & $15.50 \mathrm{fg}$ & $11.97 \mathrm{ef}$ & $7.60 \mathrm{bc}$ & $3.00 \mathrm{c}-\mathrm{f}$ \\
\hline Anexa & $51.00 \mathrm{c}$ & $92.00 \mathrm{~b}$ & $1381.67 \mathrm{~b}$ & $46.00 \mathrm{~b}$ & $33.00 \mathrm{c}$ & $18.73 \mathrm{ab}$ & $13.07 \mathrm{bcd}$ & $6.73 \mathrm{ef}$ & $3.07 \mathrm{~b}-\mathrm{e}$ \\
\hline Yaldız & $50.33 \mathrm{c}$ & $92.67 \mathrm{~b}$ & $1693.33 \mathrm{a}$ & $45.67 \mathrm{~b}$ & $29.83 \mathrm{e}$ & $18.83 \mathrm{a}$ & $14.67 \mathrm{a}$ & $8.17 \mathrm{ab}$ & $3.83 \mathrm{a}$ \\
\hline R.Charisma & $49.83 \mathrm{~cd}$ & $76.33 \mathrm{~cd}$ & $1403.33 \mathrm{~b}$ & $35.73 \mathrm{gh}$ & $30.27 \mathrm{de}$ & $18.13 \mathrm{ab}$ & $13.17 \mathrm{bcd}$ & $7.17 \mathrm{cde}$ & $3.23 \mathrm{bc}$ \\
\hline Bandolero & $47.00 \mathrm{de}$ & $93.00 \mathrm{~b}$ & $1325.00 \mathrm{~b}$ & $42.33 \mathrm{~cd}$ & $27.33 \mathrm{f}$ & $17.90 \mathrm{bc}$ & $12.53 \mathrm{def}$ & $6.80 \mathrm{def}$ & $3.23 \mathrm{bc}$ \\
\hline Huzaro & $46.83 \mathrm{e}$ & $91.00 \mathrm{~b}$ & $1208.33 \mathrm{~cd}$ & $43.00 \mathrm{~cd}$ & $32.33 \mathrm{~cd}$ & $17.07 \mathrm{~cd}$ & $12.33 \mathrm{def}$ & $6.90 \mathrm{def}$ & $2.87 \mathrm{c}-\mathrm{f}$ \\
\hline Davaro & $45.33 \mathrm{ef}$ & $77.33 \mathrm{~cd}$ & $1323.33 \mathrm{~b}$ & $40.67 \mathrm{de}$ & $33.33 \mathrm{c}$ & $16.10 \mathrm{ef}$ & $12.87 \mathrm{~b}-\mathrm{e}$ & $6.60 \mathrm{efg}$ & $3.17 \mathrm{bcd}$ \\
\hline Klimaro & $42.67 \mathrm{fg}$ & $80.33 \mathrm{c}$ & $905.00 \mathrm{e}$ & $41.00 \mathrm{~d}$ & $33.67 \mathrm{bc}$ & $14.00 \mathrm{~h}$ & $13.83 \mathrm{ab}$ & $8.67 \mathrm{a}$ & $3.43 \mathrm{ab}$ \\
\hline Pedro & $41.33 \mathrm{gh}$ & $73.33 \mathrm{~d}$ & $1195.00 \mathrm{~cd}$ & $33.50 \mathrm{~h} 1$ & $21.83 \mathrm{~h}$ & $15.83 \mathrm{efg}$ & $13.27 \mathrm{bcd}$ & $6.83 \mathrm{def}$ & $3.00 \mathrm{c}-\mathrm{f}$ \\
\hline Remala & $40.10 \mathrm{gh} 1$ & $77.07 \mathrm{~cd}$ & $1147.00 \mathrm{~cd}$ & 38.33 ef & $35.90 \mathrm{ab}$ & $15.07 \mathrm{~g}$ & $13.77 \mathrm{abc}$ & 5.631 & $3.03 \mathrm{~b}-\mathrm{e}$ \\
\hline Ametist & $39.33 \mathrm{~h} 1$ & $65.33 \mathrm{e}$ & $1175.00 \mathrm{~cd}$ & 32.831 & $21.50 \mathrm{~h}$ & $16.50 \mathrm{de}$ & $12.77 \mathrm{cde}$ & $7.40 \mathrm{~cd}$ & $2.67 \mathrm{efg}$ \\
\hline Alex & $37.33 \mathrm{1j}$ & $61.67 \mathrm{e}$ & $970.00 \mathrm{e}$ & $33.67 \mathrm{~h} 1$ & $23.33 \mathrm{gh}$ & $13.67 \mathrm{~h}$ & $12.73 \mathrm{cde}$ & $7.00 \mathrm{c}-\mathrm{f}$ & $2.33 \mathrm{~g}$ \\
\hline Maestro & $36.33 \mathrm{j}$ & $64.67 \mathrm{e}$ & $1216.67 \mathrm{~cd}$ & $36.90 \mathrm{fg}$ & $25.33 \mathrm{fg}$ & $16.67 \mathrm{de}$ & $13.20 \mathrm{bcd}$ & $6.07 \mathrm{gh} 1$ & $2.80 \mathrm{~d}-\mathrm{f}$ \\
\hline Significant & $* *$ & $* *$ & $* *$ & $* *$ & $* *$ & $* *$ & $* *$ & $* *$ & $* *$ \\
\hline CV & 3.7 & 3.2 & 4.3 & 3.7 & 4.6 & 3.3 & 4.8 & 5.3 & 7.9 \\
\hline
\end{tabular}

The color of the outer leaf varied between green, dark green, and dark violet. The color of the outer leaf was determined as green in the varieties of Resima, Caballero, Klimaro; dark green in the Bandolero, Anexa, Remala, and Huzaro varieties; and dark violet in the other varieties (Table 3). It was determined that the color intensity of the outer leaf was mainly in dark tones. Except for Bandolero, Remala, Pedro, and Red Charisma cultivars, the leaf margins of the other varieties were found to have a teethed structure (Table 3).

The outer leaf angle of the cultivars was examined as vertical angle $\left(87^{\circ}<\right)$, open $\left(\sim 67^{\circ}\right)$, half slant $\left(\sim 45^{\circ}\right)$, slant $\left(<30^{\circ}\right)$ and drooping $\left(<-10^{\circ}\right)$. The outer leaf angle is determined as the half slant in Anexa variety; as slant in Klimaro, Ametist, Pedro and Maestro varieties; as open in Bandolero, Remala, Alex, Davaro, Huzaro and Red Taste varieties; as the vertical angle in Yaldız, Resima, Caballero and Red Charisma varieties (Table 3).

With the increasing world population, it has come to the fore to increase efficiency to get more efficiency from the unit area (Çay and Aykaş, 2013). The yield is directly related to the size of the head and firmness, and the head size of the redhead cabbage is generally between 1-2 kg (Kar and Karaağaç, 2016). In the research, the head weights of varieties varied between $905.0 \mathrm{~g}$ and $1693.33 \mathrm{~g}$. The highest head weight was determined in the Yaldiz variety, and the lowest head weight was determined in the Klimaro variety (Table 2). The hardness of the head was determined as tight in all varieties. Acar and Paksoy (2006) reported that the head weight was $625.08 \mathrm{~g} \mathrm{~cm}$ in the ACN-33 F1 variety and $678.5 \mathrm{~g}$ in the Royal F1 variety. Padem and Güvenç (2007) reported the head weight as $820 \mathrm{~g}$ to $2142.0 \mathrm{~g}$ among red head cabbage varieties; Tıraşçı (2016) determined the head weight as $907.50 \mathrm{~g}$ in Mohrenkopf variety. Similarly, Demirboğa (2016) determined the head weight as 814.0 g; Salwa et al. (2019) reported as $1.12 \mathrm{~g}$. They reported that different varieties might come to the fore in changing environments depending on the adaptability of the varieties and the environmental conditions in which they are grown (Ece and Güler, 2017).

In the study, the head diameters of the cultivars showed relative values, with the lowest in Caballero (11.53 $\mathrm{cm})$ and the highest in Yaldız $(14.67 \mathrm{~cm})$ varieties. Head length values ranged from $13.67 \mathrm{~cm}$ to $18.83 \mathrm{~cm}$. The lowest head length is determined in Alex and the highest head length in Yaldiz varieties (Table 2). In studies conducted by different researchers, head diameter values were between $6.83 \mathrm{~cm}$ to $22.8 \mathrm{~cm}$; head lengths were found to be between $10.65 \mathrm{~cm}$ to $19.7 \mathrm{~cm}$ (Onus and Polat, 2000; Padem and Güvenç, 2007; Thapa and Prasad, 2012; Demirboğa 2016; Tunc and Sahin, 2016; Maltaş et al. 2017). 
Table 3. Morphological characterization criteria of red head cabbage varieties

\begin{tabular}{|c|c|c|c|c|c|c|c|c|}
\hline \multirow[b]{2}{*}{ Traits } & \multicolumn{8}{|c|}{ Variety } \\
\hline & Yaldız & Pedro & Caballero & Bandolero & Anexa & Remala & Huzaro & Resima \\
\hline Covering of head & Covered & Covered & Covered & $\begin{array}{l}\text { Partially } \\
\text { covered }\end{array}$ & Covered & $\begin{array}{l}\text { Partially } \\
\text { covered }\end{array}$ & Covered & Covered \\
\hline Shape of head & $\begin{array}{c}\text { Broad } \\
\text { obovate }\end{array}$ & $\begin{array}{c}\text { Broad } \\
\text { obovate }\end{array}$ & $\begin{array}{c}\text { Broad } \\
\text { obovate }\end{array}$ & Elliptic & Elliptic & $\begin{array}{c}\text { Broad } \\
\text { obovate }\end{array}$ & Elliptic & $\begin{array}{c}\text { Broad } \\
\text { obovate }\end{array}$ \\
\hline Top leaf color of the head & $\begin{array}{l}\text { Dark } \\
\text { violet }\end{array}$ & $\begin{array}{l}\text { Dark } \\
\text { violet }\end{array}$ & $\begin{array}{l}\text { Dark } \\
\text { violet }\end{array}$ & $\begin{array}{c}\text { Dark } \\
\text { violet }\end{array}$ & $\begin{array}{l}\text { Dark } \\
\text { violet }\end{array}$ & $\begin{array}{l}\text { Dark } \\
\text { violet }\end{array}$ & $\begin{array}{l}\text { Dark } \\
\text { violet }\end{array}$ & $\begin{array}{c}\text { Dark } \\
\text { violet }\end{array}$ \\
\hline Hardness of head & $\begin{array}{l}\text { Very } \\
\text { tight }\end{array}$ & $\begin{array}{l}\text { Very } \\
\text { tight }\end{array}$ & $\begin{array}{l}\text { Very } \\
\text { tight }\end{array}$ & $\begin{array}{l}\text { Very } \\
\text { tight }\end{array}$ & $\begin{array}{l}\text { Very } \\
\text { tight }\end{array}$ & $\begin{array}{l}\text { Very } \\
\text { tight }\end{array}$ & $\begin{array}{l}\text { Very } \\
\text { tight }\end{array}$ & $\begin{array}{l}\text { Very } \\
\text { tight }\end{array}$ \\
\hline Outer leaf angle & $\begin{array}{l}\text { Vertical } \\
\text { angle }\end{array}$ & Slant & $\begin{array}{l}\text { Vertical } \\
\text { angle }\end{array}$ & Open & $\begin{array}{l}\text { Half } \\
\text { slant }\end{array}$ & Open & Open & $\begin{array}{l}\text { Vertical } \\
\text { angle }\end{array}$ \\
\hline The shape of the outer leaf & Spatula & Spatula & Spatula & Broad ovate & $\begin{array}{l}\text { Broad } \\
\text { ovate }\end{array}$ & Circular & $\begin{array}{l}\text { Broad } \\
\text { ovate }\end{array}$ & Spatula \\
\hline Outer leaf end shape & Round & Round & $\begin{array}{l}\text { Narrow } \\
\text { round }\end{array}$ & Round & Round & Round & Round & $\begin{array}{l}\text { Narrow } \\
\text { round }\end{array}$ \\
\hline Blistering of the outer leaf & - & - & - & - & $\begin{array}{l}\text { Very } \\
\text { weak }\end{array}$ & Weak & $\begin{array}{l}\text { Very } \\
\text { weak }\end{array}$ & - \\
\hline Size of blisters in the outer leaf & - & - & - & - & Large & Large & Large & - \\
\hline Waxiness on the outer leaf & Weak & Weak & Weak & Weak & Weak & Weak & Weak & Weak \\
\hline Color of the outer leaf & $\begin{array}{c}\text { Dark } \\
\text { violet }\end{array}$ & $\begin{array}{c}\text { Dark } \\
\text { violet }\end{array}$ & Green & $\begin{array}{l}\text { Dark } \\
\text { green }\end{array}$ & $\begin{array}{l}\text { Dark } \\
\text { green }\end{array}$ & $\begin{array}{l}\text { Dark } \\
\text { green }\end{array}$ & $\begin{array}{l}\text { Dark } \\
\text { green }\end{array}$ & Green \\
\hline $\begin{array}{l}\text { The color intensity of the outer } \\
\text { leaf }\end{array}$ & Dark & Dark & Dark & Dark & Dark & Dark & Dark & Medium \\
\hline Outer leaf teeth & Available & Absent & Available & Absent & Available & Absent & Available & Available \\
\hline The internal color of the head & Violet & $\begin{array}{c}\text { Dark } \\
\text { violet }\end{array}$ & Violet & $\begin{array}{c}\text { Dark } \\
\text { violet }\end{array}$ & $\begin{array}{c}\text { Dark } \\
\text { violet }\end{array}$ & $\begin{array}{c}\text { Dark } \\
\text { violet }\end{array}$ & $\begin{array}{c}\text { Dark } \\
\text { violet }\end{array}$ & $\begin{array}{c}\text { Dark } \\
\text { violet }\end{array}$ \\
\hline $\begin{array}{l}\text { Maximum width region of the } \\
\text { head }\end{array}$ & $\begin{array}{l}\text { in the } \\
\text { middle }\end{array}$ & $\begin{array}{l}\text { in the } \\
\text { middle }\end{array}$ & $\begin{array}{l}\text { in the } \\
\text { middle }\end{array}$ & $\begin{array}{l}\text { in the } \\
\text { middle }\end{array}$ & $\begin{array}{l}\text { in the } \\
\text { middle }\end{array}$ & $\begin{array}{l}\text { in the } \\
\text { middle }\end{array}$ & $\begin{array}{l}\text { in the } \\
\text { middle }\end{array}$ & $\begin{array}{l}\text { in the } \\
\text { middle }\end{array}$ \\
\hline $\begin{array}{l}\text { The shape of the base in the } \\
\text { longitudinal section }\end{array}$ & Rounded & Rounded & Rounded & Rounded & Rounded & Rounded & Rounded & Rounded \\
\hline Time of harvest maturity & 95 & 87 & 115 & 115 & 115 & 68 & 115 & 115 \\
\hline Resistance to cracking & High & High & High & High & High & High & High & High \\
\hline $\begin{array}{l}\text { Duration of mature heads in the } \\
\text { field }\end{array}$ & Long & Long & Long & Long & Long & Long & Long & Long \\
\hline
\end{tabular}

Table 3 (continued)

\begin{tabular}{|c|c|c|c|c|c|c|c|}
\hline \multirow[b]{2}{*}{ Traits } & \multicolumn{7}{|c|}{ Variety } \\
\hline & Maestro & $\begin{array}{l}\text { Red } \\
\text { Taste }\end{array}$ & $\begin{array}{c}\text { Red } \\
\text { Charisma }\end{array}$ & Alex & Davaro & Ametist & Klimaro \\
\hline Covering of head & $\begin{array}{l}\text { Partially } \\
\text { covered }\end{array}$ & Covered & Covered & $\begin{array}{l}\text { Partially } \\
\text { covered }\end{array}$ & Covered & Covered & Covered \\
\hline Shape of head & $\begin{array}{l}\text { Broad } \\
\text { obovate }\end{array}$ & $\begin{array}{l}\text { Broad } \\
\text { obovate }\end{array}$ & Elliptic & $\begin{array}{l}\text { Broad } \\
\text { obovate }\end{array}$ & $\begin{array}{l}\text { Broad } \\
\text { obovate }\end{array}$ & $\begin{array}{c}\text { Broad } \\
\text { obovate }\end{array}$ & Round \\
\hline Top leaf color of the head & $\begin{array}{l}\text { Dark } \\
\text { violet }\end{array}$ & $\begin{array}{c}\text { Dark } \\
\text { violet }\end{array}$ & $\begin{array}{l}\text { Dark } \\
\text { violet }\end{array}$ & $\begin{array}{l}\text { Dark } \\
\text { violet }\end{array}$ & $\begin{array}{l}\text { Dark } \\
\text { violet }\end{array}$ & $\begin{array}{l}\text { Dark } \\
\text { violet }\end{array}$ & $\begin{array}{l}\text { Dark } \\
\text { violet }\end{array}$ \\
\hline Hardness of head & $\begin{array}{l}\text { Very } \\
\text { tight }\end{array}$ & $\begin{array}{l}\text { Very } \\
\text { tight }\end{array}$ & $\begin{array}{l}\text { Very } \\
\text { tight }\end{array}$ & $\begin{array}{l}\text { Very } \\
\text { tight }\end{array}$ & $\begin{array}{l}\text { Very } \\
\text { tight }\end{array}$ & $\begin{array}{l}\text { Very } \\
\text { tight }\end{array}$ & $\begin{array}{l}\text { Very } \\
\text { tight }\end{array}$ \\
\hline Outer leaf angle & Slant & Open & $\begin{array}{l}\text { Vertical } \\
\text { angle }\end{array}$ & Open & Open & Slant & Slant \\
\hline The shape of the outer leaf & $\begin{array}{l}\text { Broad } \\
\text { ovate }\end{array}$ & Spatula & Spatula & Circular & Circular & Spatula & Circular \\
\hline Outer leaf end shape & Round & Round & Round & Round & Round & Round & Round \\
\hline Blistering of the outer leaf & - & - & - & - & - & - & Medium \\
\hline Size of blisters in the outer leaf & - & - & - & - & - & & Large \\
\hline Waxiness on the outer leaf & Weak & Medium & Strong & Weak & Weak & Weak & Strong \\
\hline Color of the outer leaf & $\begin{array}{c}\text { Dark } \\
\text { violet }\end{array}$ & $\begin{array}{l}\text { Dark } \\
\text { violet }\end{array}$ & $\begin{array}{c}\text { Dark } \\
\text { violet }\end{array}$ & $\begin{array}{c}\text { Dark } \\
\text { violet }\end{array}$ & $\begin{array}{l}\text { Dark } \\
\text { violet }\end{array}$ & $\begin{array}{l}\text { Dark } \\
\text { violet }\end{array}$ & Green \\
\hline The color intensity of the outer leaf & Dark & Dark & Dark & Dark & Dark & Dark & Dark \\
\hline Outer leaf teeth & Available & Available & Absent & Available & Available & Available & Available \\
\hline The internal color of the head & $\begin{array}{c}\text { Dark } \\
\text { violet }\end{array}$ & $\begin{array}{c}\text { Dark } \\
\text { violet }\end{array}$ & $\begin{array}{c}\text { Dark } \\
\text { violet }\end{array}$ & $\begin{array}{c}\text { Dark } \\
\text { violet }\end{array}$ & $\begin{array}{c}\text { Dark } \\
\text { violet }\end{array}$ & $\begin{array}{c}\text { Dark } \\
\text { violet }\end{array}$ & $\begin{array}{l}\text { Light } \\
\text { violet }\end{array}$ \\
\hline Maximum width region of the head & $\begin{array}{l}\text { in the } \\
\text { middle }\end{array}$ & $\begin{array}{l}\text { in the } \\
\text { middle }\end{array}$ & $\begin{array}{l}\text { in the } \\
\text { middle }\end{array}$ & $\begin{array}{l}\text { in the } \\
\text { middle }\end{array}$ & $\begin{array}{l}\text { in the } \\
\text { middle }\end{array}$ & $\begin{array}{l}\text { in the } \\
\text { middle }\end{array}$ & $\begin{array}{l}\text { in the } \\
\text { middle }\end{array}$ \\
\hline $\begin{array}{l}\text { The shape of the base in the } \\
\text { longitudinal section }\end{array}$ & Rounded & Rounded & Rounded & Rounded & Rounded & Rounded & Rounded \\
\hline Time of harvest maturity & 87 & 95 & 125 & 87 & 87 & 87 & 115 \\
\hline Resistance to cracking & High & High & High & High & High & High & High \\
\hline Duration of mature heads in the field & Long & Long & Long & Long & Long & Long & Long \\
\hline
\end{tabular}

The length of the head stem varied between $5.63 \mathrm{~cm}$ and $8.67 \mathrm{~cm}$, and the diameter of the head stem varied between $2.33 \mathrm{~cm}$ and $3.83 \mathrm{~cm}$ among all varieties. The shortest length of the head stem was measured in the 
Remala variety, and the highest length of the head stem was measured in the Klimaro variety. The lowest diameter of the head stem was found in the Alex variety, and the highest diameter of the head stem was found in the Yaldiz variety (Table 2). Aşçığul (2009) determined the length of head stem as $11.0 \mathrm{~cm}$ and the diameter of the head stem as $4.0 \mathrm{~cm}$ in the redhead cabbage.

The shape of the head varied between broad obovate, elliptic and round in red head cabbage varieties. The head shape of the Klimaro variety was determined as round. The head shape was determined as elliptic in Bandolero, Anexa, Huzaro and Red Charisma varieties. In other varieties, it was observed as broad obovate (Table 3).

Covering the upper part of the head with outer leaves is a desirable feature as it protects the head from external factors. (Kar and Karaağaç, 2016). It was determined that the heads were covered with outer leaves in most of the cultivars. One of the characteristics examined in the heads was the interior color of the head. The dark violet interior color of the head was the most common among the varieties. Also, it was determined that the interior color of the head was light violet in the Klimaro variety and violet in the Caballero and Yaldız varieties (Table 3).

It was determined that the maximum width region of the head was in the middle in all varieties and the base shape in the longitudinal section was round. The top leaf colors of the head varieties were determined visually. As a result of the observation, it was determined that the top leaf color of the head varieties was dark violet (Table 3).

The time from seedling planting of varieties to the harvest maturity of the heads varied between 68 and 125 days. Remala was the earliest variety, while the latest was Red Charisma. Also, it was observed that all varieties remained on the field for a considerable time without cracking (Table 3).

\section{Conclusions}

Red head cabbage is among the significant winter vegetables produced mainly in various parts of the world and Turkey. Vegetable growers prefer to use hybrid seeds due to their advantages. In Turkey, hybrid seeds are used in the production of red head cabbage. In the study, morphological characterization of 15 different hybrid red cabbage varieties was made. It was determined that the varieties showed great variety in terms of the characteristics examined. The study revealed that the variety with the best performance in terms of head weight, head length, and head diameter, traits affecting yield was Yaldız. In addition, Caballero has become prominent in terms of plant height. On the other hand, Red Taste has become prominent in terms of plant width features. It was determined that the earliest variety was Remala while the latest variety was Red Charisma. It was determined that the heads in all varieties could remain in the field for a long time without cracking.

\section{Acknowledgment}

The study was supported by The Scientific and Technological Research Council of Turkey (TUBITAK) Project No: 117G002 (Line and / or Variety Development Project in Winter Vegetable Growing. 


\section{References}

Acar, B., Paksoy, M. (2006). Effect of different irrigation methods on red cabbage (Brassica oleraceae L. var. capitata subvar. f. rubra) yield and some plant characteristics. Pakistan Journal of Biological Sciences. 9 (13): 2531-2534

Aşçıŏ̆ul, T.K. (2009). Bazı Lahana Genotiplerinin Morfolojik Ve Moleküler Tanımlanmasına Yönelik Araştırmalar. (Ph. D. Thesis). Ege Üniversity The Institute of Natural Sciences, İzmir, Turkey.

Çay, A., Aykaş, E. (2013). Domates üretiminde farklı fide yatağı hazırlığı yöntemleri ve örtü bitkisi uygulamasının verim ve hasat sonrası kalite parametrelerine etkileri. Tekirdă̆ Ziraat Fakültesi Dergisi. 10 (1): 105-114.

Demirboğa, G. (2016). Kırmızı Baş Lahana (Brassica oleracea var. capitata subvar. F. rubra) Yetiştiriciliği Iç̧in Uygun Ekim Zamanı ve Çeşitlerinin Belirlenmesi Üzerine Bir Araştırma (Master Thesis), Gaziosman Paşa Üniversity The Institute of Natural Sciences, Tokat, Turkey.

Ece, A., Güler, S. (2017). Kızılırmak’ta (Çankırı) ikici ürün olarak kullanılabilecek alternatif sebze türlerinin belirlenmesi. Tekirdă̆ Ziraat Fakültesi Dergisi. 14 (01): 38-47.

IBPGR (1990). Descriptors for Brassica and Raphanus. International Board for Plant Genetic Resources, Rome, 51

Kar, H., Karaağaç, O. (2016). Türkiyede baş lahana 1slahı. Türktob, 5 (20): 24-29.

Maltaş, A.Ş., Tavalı, İ.E., Uz, İ., Kaplan, M. (2017). Kırmızı baş lahana (Brassica oleracea var. capitata f. rubra) yetiştiriciliğinde vermikompost uygulamas1. Mediterranean Agric Sciences. 30 (2): 155-161.

Monteiro, A., Lunn, T. (1998). Trends and perspectives of vegetable Brassica breeding World-Wide. World Conference on Horticultural Research. 17-20 June 1998, Rome, Italy.

Onus, N., Polat, E. (2000). Bazı kırmızı ve baş lahana (Brassica oleracea var. capitata) çeşitlerinin Antalya koșullarında adaptasyonu. Derim 17 (4): 178-184.

Padem, H., Güvenç, İ. (2007). Farklı dikim zamanlarının kırmızı baş lahanada (Brassica oleracea var. capitata subvar. f. rubra) bitki gelişmesi, verim ve bazı kalite özelliklerine etkisi. Atatürk Ü.Zir.Fak.Der. 28 (3): 405-412.

Salwa, M., Solaiman, A.H.M., Haq, Md. 1 E., Hossain, Md. D., Siddika, A., Tanzina Baby, T., Akther, E., Halder, O. (2019). Effect of vermicompost and plant vitalizer on growth and yield of red cabbage (Brassica oleraceae L. var capitata). Asian Journal of Research in Botany. 2(4): 1-15.

Song, K.M., Osborn, T.C., Williams, P.H. (1988). Brassica taxonomy based on nuclear restriction fragment length polymorphisms (RFLPs): 2. Preliminary analysis of subspecies within B. rapa (syn. campestris) and B. oleracea. Theoretical and Applied Genetics 76: 593-600

Song, K., Osborn, T. C., Williams, P.H. (1990). Brassica taxonomy based on nuclear restriction fragment length polymorphisms (RFLPs): 3. Genome relationships in Brassica and related genera and the origin of B. oleracea and B. rapa (syn. campestns). Theoretical and Applied Genetics. 79: 497-506

Thapa, U., Prassad, P.H. (2012). Studies on evaluation for adoption of high value cole crops in the plains of West Bengal. Proceedings SEAVEG, 24-26 January, Chiang Mai, Thailand.

Tıraşçı, S. (2016). Erzurum Koşullarında Kırmızı Lahana (Brassica oleracea L. var. rubra) ve Marul (Lactuca sativa L.) Birlikte Yetiştiriciliğinin Bitki Gelişimi, Verim ve Alan Eşdeğer Oranı Üzerine Etkisi (Master Thesis), Atatürk Üniversity The Institute of Natural Sciences, Erzurum, Turkey.

TUİK (2018). Turkish Statistical Institute. Crop Production Statistics, Ankara. http://www.tuik.gov.tr/bitkiselapp/bitkisel.zul (date of access: 11.08.2020)

Tunc, T., Sahin, U. (2016). Red cabbage yield, heavy metal content, water use and soil chemical characteristics under wastewater irrigation. Environ Sci Pollut Res. 23:6264-6276.

UPOV (2004). Cabbage, TG/48/7. Guidelines for the conduct of tests for distinctness, uniformity and stability. International Union For The Protection of New Varieties of Plants, Geneva, $36 \mathrm{p}$.

Yağmur, B., Kavak, S., Uğur, A., Bozokalfa, M.K., Eşiyok, D. (2003). Potasyum uygulamalarının savoy lahanasında (Brassica oleracea L. var. sabauda) verim ve kalite özellikleri üzerine etkisi. Ege Üniversitesi Ziraat Fakültesi Dergisi, 40(2): 113-120.

Zhou, W.J. (2001). Oilseed rape G.P. Zhang W.J. Zhou (Eds) Crop Cultivation Zhejiang University Press Hangzhou, China 153-178.

Zhou, W.J., Zhang, G.Q., Tuvesson, S., Dayteg, C., Gertsson, B. (2006). Genetic survey of Chinese and Swedish oilseed rape (Brassica napus L.) by simple sequence repeats (SSRs). Genetic Resources and Crop Evolution, 53 (3), 443-447 